\title{
Communication Skills of Village Officers Viewed From Their Ability in Utilizing Social Media
}

\author{
S Aw ${ }^{1}$, W Handayani², N Y Laksana ${ }^{3}$ \\ ${ }^{123}$ Department of Communication Sciences Universitas Negeri Yogyakarta, Yogyakarta Indonesia \\ ${ }^{1}$ suranto@uny.ac.id, ${ }^{2}$ wuri.handayani@uny.ac.id, ${ }^{3}$ laksanayudha@uny.ac.id
}

\begin{abstract}
This research focuses on analyzing and describing the communication skills in utilizing social media among village officers. Communication skills include the ability to send and receive messages using social media. This research is a descriptive research with a saturated sample, where all village officers (35 people) in Umbulmartani Village, Ngemplak, Sleman, Yogyakarta Special Province become the research respondents. The data were collected using a questionnaire in the Google form format. Data analysis was performed using frequency distribution techniques with percentages. The results show a tendency that most village officers have the ability to use social media in a good category. The obstacles in increasing their skills in using social media include: age and relatively low educational background.
\end{abstract}

Keywords. communication, village officers, social media

\section{Introduction}

Globalization which goes along with technological advancement has led the world to the industrial revolution 4.0 era which is characterized by the phenomenon of disruptive innovation. This new era is marked by the development of digital communication patterns and place communication as one of the primary needs, both for personal and organizational life. Today, communication plays a vital role for the interests of the government, economy, socioculture, and education. Communication is widely and increasingly used to improve performance, both for financial and network aspects [1]. Another view states that communication is an information management process. Information becomes an invaluable asset and an important commodity for the consideration of decision making by the organization [2].

Communication is a process of transmitting the symbol from the source to the recipient. The symbol is intentionally created and delivered in a certain way based on the characteristics of the recipient. For an organization, communication holds an important meaning. [3] states that skills to communicate with internal and external people of the organization are badly needed to achieve organizational success, both business and social organizations. In regard to the organizational management, [4] says that there are five aspects that must be addressed in managing the organization professionally, namely: problem-solving ability, reasoning, communication, connection, and representation. The results of the Pennsylvania State University survey on the main capabilities required by the job market, both in government and private institutions, include:

1. Oral and written communication skills $(83.5 \%)$

2. Leadership (79.7\%)

3. Analytical ability $(75.3 \%)$

4. Teamwork $(71.4 \%)$ 
5. Ability to handle rapid changes $(65.9 \%)$

6. Social, professional, and ethical responsibility (64.3)

7. Financial management $(46.7 \%)[5]$

Based on that study, communication skill is one of the important skills that must be acquired by employees in different workplaces. Communication becomes an essential part of the dynamics of organizational management. Communication competence is the ability to communicate with, within, or about any type of work. [6] Communication can be defined as a process in which information can be exchanged between individuals through a system of symbols, signs, or behavior. Therefore, communication includes the sender and receiver, and the media in which both can understand the information being communicated. Other communication experts state that communication is the act of transmitting and receiving information [7]. This is supported by the statement of [8] that communication is a way of sharing ideas and clarifying meaning. Through communication, an idea becomes an object of reflection, refinement, discussion, and understanding.

Communication may occur in many different ways, namely in the form of thinking, talking, discussing, drawing, and painting. In this case, the discussion that occurs raises dialogue between individuals [9]. Dialogue can generally be defined as a chain of speech where each utterance influences responses, responses and subsequent reactions that are generated between individuals and will lead the communication in a particular direction. In this context, speech works as a 'language in action' in communication [10].

By observing the technological advancement and the development of activities in all organizations - including the current village government organizations, becoming an employee or professional village officer provides a challenge and strategic opportunity. An employee is required to have adequate capability and capacity because they play an important role in determining or influencing the success or failure of the office, company, or organizational activities. Today, information holds a very important role, both in the interests of the government, economy, social culture, and education. Therefore, it is necessary to change the mindset that perceives information and communication infrastructure as a complement and driver. The mindset must be changed in accordance with global conditions that require Information and Communication Technology (ICT) to be the driving force of development.

In general, the fact shows that the distribution of communication media (especially social media based on cellular or smartphone technology) has reached villages. The number of Smartphone users in Umbulmartani Village is very high. The Umbulmartani Village Monograph (2019) shows that there are at least 4500 smartphone users in Umbulmartani. With a population of 6625 people, more than $67.9 \%$ of the population are smartphone users. In addition, there are 3124 households in Umbulmartani Village, thus the number of smartphone users is greater than the number of households. This indicates that one household will possibly have more than one smartphone device.

\section{Methods}

This research is descriptive research utilizing a saturated sample, in which 35 village officials in Umbulmartani Village, Ngemplak, Sleman, Yogyakarta Special Region becomes the research respondents. The data were collected using a questionnaire in the Google form format. Data analysis employs descriptive analysis techniques in the form of frequency 
distribution with percentages, averages, and the conversion of quantitative data to qualitative data. The following is presented a descriptive analysis technique utilized in this research.

1) Trends measurement utilizes percentages, where percentage calculation is used to calculate the percentages of each component based on the frequency of respondents' answers using the following formula:

Percentage $=\underline{\mathrm{F}} \times 100 \%$

where:

F : Frequency of respondents within a category

$\mathrm{N}$ : Total number of cases

2) The mean score is calculated using the following formula.

$\mu \mathrm{x}=\sum_{\mathrm{N}} \mathrm{X}_{\mathrm{i}}$

where:

$\mu \mathrm{x} \quad$ : Mean

$\sum \quad:$ Total

$\mathrm{X}_{\mathrm{i}} \quad$ : Variable score

$\mathrm{N}$ : Number of individuals or respondents (Rasyid, 1994:12).

3) The conversion of quantitative data to qualitative data on a scale of 5 is presented as follows.

Table 1.The conversion of quantitative data to qualitative data

\begin{tabular}{|c|c|c|}
\hline Formula & Mean Score & Classification \\
\hline $\mathrm{X}>\mu \mathrm{X}_{\mathrm{i}}+1,8 \times \mathrm{sb}_{\mathrm{i}}$ & $>4.2$ & Very Good \\
\hline$\mu X_{i}+0,6 \times s_{i}<X \leq \mu X_{i}+1,8 \times s_{i}$ & $>3.4-4.2$ & Good \\
\hline$\mu X_{i}-0,6 \times s_{i}<X \leq \mu X_{i}+0,6 \times s_{i}$ & $>2.6-3.4$ & Acceptable \\
\hline$\mu X_{i}-1,8 \times$ sb $_{i}<X \leq \mu X_{i}+0,6 \times s b_{i}$ & $>1.8-2.6$ & Poor \\
\hline $\mathrm{X} \leq \mu \mathrm{X}_{\mathrm{i}}-1,8 \times \mathrm{sb}_{\mathrm{i}}$ & $\leq 1.8$ & Very Poor \\
\hline
\end{tabular}

where:

$\mu \mathrm{X}_{\mathrm{i}}($ ideal mean $)=($ ideal maximum score + ideal minimum score $) / 2$

$\mathrm{Sb}_{\mathrm{i}}($ ideal standard deviation $)=1 / 6$ (ideal maximum score - ideal minimum score)

$\mathrm{X}=$ empirical score

\section{Results And Discussions}

The ability of village officers to communicate viewed from their ability to use social media is the ability to utilize social media as a tool to help ease the process of producing, sending, and receiving messages. The focus of this research is to obtain information on the degree of their ability in using social media. The ability level criterion is determined using descriptive analysis by converting quantitative data to qualitative data with a scale of 5 . The level of communication ability is declared to be good if the mean score is in the range of $>3.4-4.2$ (good category).

Based on those criteria, the results of this research as presented in table 2 with a total mean score of 4.03 indicate that the achievement of organizational objectives belongs to a good category. 
Table 2: Data Description on Communication Capabilities of Using Social Media

\begin{tabular}{clc}
\hline \multicolumn{1}{c}{ No. } & \multicolumn{1}{c}{ Aspects being assessed } & Mean score \\
\hline 1. & Compose written/chat messages & 4,03 \\
\hline 2. & Ensure the messages based on data and facts & 3,96 \\
\hline 3. & Update the status & 3,82 \\
\hline 4. & Make phone and video calls & 4,00 \\
\hline 5. & Create a new group on the WhatsApp application & 3,82 \\
\hline 6. & Understand and analyze information received & 3,96 \\
\hline 7. & Respond to information that is indicated as a hoax & 3,82 \\
\hline 8. & Consider ethics and responsibility & 4,85 \\
\hline & Mean of total score & $\mathbf{4 , 0 3}$ \\
\hline
\end{tabular}

The descriptive analysis based on data obtained from the questionnaire filled out by 35 research respondents shows that the communication skill aspect viewed from the ability in using social media which has the highest score is the ability to communicate with ethics and responsibilities. Its mean score is 4.85 and belongs to the classification of very good $(>4.2)$. This finding indicates that respondents understand the ethical principles of communication, and have applied them in the process of sending and receiving information via social media.

Meanwhile, the low ability includes the ability to update the status, create a new group on the WhatsApp application, and respond to information that is indicated as a hoax, with a mean score of 3.82 within a good category(3.4 - 4.2). This finding shows that some village officials still have limitations in utilizing social media, mainly due to the factors of age and formal education levels.

In general, the findings of this study illustrate the intensity of the use of social media among village officers. Social media is used to communicate and socialize for improving performance and strengthening social networks. The role of communication skills to enhance performance is explained by [11] "...in the new global and diverse workplace requires excellent communication abilities. People communicate to plan products and services; hire, train, and motivate workers; coordinate manufacturing and delivery; persuade customer to buy; and bill them for the sale." This is relevant to the tendency that people use social media to socialize and find information. Many applications that support for socializing such as WhatsApp, twitter, blackberry messanger, facebook, line, path and etc.

Furthermore, [12] reveals the fact of the increasing use of mobile devices as the communication media choice for all parties. The point is that internet-based mobile phone technology has transformed massively from the beginning as a means of making a phone call and send short messages, becoming a sophisticated and complete communication media.

Unfortunately, the current development of the media in Indonesia is not linear compared to equal access to information. Although the distribution of media devices has reached remote villages, communication skills in using smartphone-based social media to obtain information and education are still low. This correlates with "media literacy" which is still dominated by people from the middle to the upper class. [13] says that the diversity of media has not been able to represent a "success media" but it represents "disseminated media". Communication skills are illustrated by the use of social media to produce, send, and receive messages [14]. 


\section{Conclusion}

The results of the research show the tendency of most village officers to have the ability to use social media in a good category indicated with an average score of 4.03 out of 5 . Communication using social media is performed to support performance as a village officer, as well as to foster good relations within the social networks. The constraints in increasing the ability to use social media include the factors of old age and a relatively low educational background.

\section{References}

[1] Suwatno: Introduction to contemporary public relations(Pengantar public relations kontemporer. Bandung: PT. Remaja Rosdakarya. p. 8-9 (2018).

[2] Gaol, C.J.L.: Sistem informasi manajemen. Jakarta: Grasindo (2008).

[3] Bovee, C.L. \& Thill, J.V. : Komunikasi bisnis edisi ke delapan. Terjemahan Doddi Prastuti. Jakarta: Indeks. (2007).

[4] Aw, S.: Developing an Evaluation Instrument for Communication Program between Vocational High Schools and Industries. TEM Journal, Volume 8, Issue 1, p. 228-233 (2019).

[5] Tubbs, S.L. \& Moss, S.: Human Communication: konteks-konteks komunikasi. PT Remaja Rosdakarya. (2000).

[6] Armas,A.M., Unde,A.A., \& Fatimah,J.M.: Konsep Diri dan Kompetensi Komunikasi Penyandang Disabilitas dalam Menumbuhkan Kepercayaan Diri dan Aktualisasi Diri di Dunia Kewirausahaan Kota Makassar. KAREBA: Jurnal Ilmu Komunikasi, 6(2), 277-284 (2017).

[7] Silalahi, U.: Komunikasi Pemerintahan: Mengirim dan Menerima Informasi Tugas dan Informasi Publik. Jurnal Administrasi Publik, 3(1) (2004).

[8] Soffer, O.: The Internet and National Solidarity: A Theoretical Analysis. Communication Theory Journal Volume 23, Issue 1 February 2013 p. 48-61 (2013).

[9] Bentley, D.\& Watts, M. Communicating in School Science: Groups, Tasks and Problem Solving 5- 16. UK dan USA: The Falmer Press, Taylor \& Francis Inc. (2005).

[10] Bakhtin, M.M.: Speech genres and other late essays. USA: University of Texas Press (2010).

[11] Locker, K.O. \& Kaczmarek, S.K.: Business communication: Building critical skills. New York, NY: McGraw-Hill Higher Education (2009).

[12] Carroll, A. \& Heiser, G. An analysis of power consumption in a smartphone. In USENIX annual technical conference.Vol. 14, pp. 21-21 (2010).

[13] Wahyuni, H.I.: Ilmu Komunikasi untuk Memuliakan Martabat Bangsa. A paper presented on National Seminar of Communication Science Study Program FIS UNY 7 April 2015.

[14] Aw, S.: An Evaluation of a Public Relations Program in Promoting Syinergistic Cooperation between Schools and Industries". Problems and Perspectives in Management Journal, Volume 16 Nomor 4. pp.353-364 (2019). 